\title{
Breathing Pneumatology: Spirit, Wind, and Atmosphere in a Zulu Zionist Congregation
}

\author{
Rune Flikke
}

This chapter is based on three years of ethnographic fieldwork among a group of Zulu Zionists in an urban township in the vicinity of Durban, South Africa. The Zionists are part of the African Independent Churches (AICs) and were for the largest part of the twentieth century the most rapidly growing religious movement in Africa south of the Sahara. ${ }^{1}$

There has long been a fruitful academic exchange between theologians and anthropologists in research into Zulu Zionism and the AICs. Academic studies of the movement first gained momentum through the work of the Swedish missionary Bengt Sundkler. ${ }^{2}$ His publications were ethnographically rich, detailed, culturally embedded, and imbued with a sound historical awareness, thereby opening up a sociological understanding of the Zionist movement. Sundkler's work was followed by a series of publications in missiology and anthropology which largely pursued his lead, interpreting the rise of the AICs as a reaction towards the paternalism, racism, and general exclusion experienced in the larger colonial society as well as the mission churches. ${ }^{3}$ Several of these

1 David B. Barrett, Schism and Renewal in Africa: An Analysis of Six Thousand Contemporary Religious Movements (Nairobi: Oxford University Press, 1968).

2 Eg. Bengt G.M. Sundkler, Bantu Prophets in South Africa. Second, expanded ed. (London, Lutterworth Press, 1948); Bengt G.M. Sundkler, Zulu Zion and Some Swazi Zionists (Oxford: Oxford University Press, 1976); See also Bengt G.M. Sundkler and Christopher Steed, A History of the Church in Africa, ed. C. Steed (Cambridge: Cambridge University Press, 200o).

3 Eg. Barrett, Schism and Renewal; Jean Comaroff, Body of Power, Spirit of Resistance: The Culture and History of a South African people (Chicago and London: University of Chicago Press, 1985); Marthinus L. Daneel, Zionism and Faith-Healing in Rhodesia (The Hague: Mouton and Co., 1970); Jim P. Kiernan, The Production and Management of Therapeutic Power in Zionist Churches Within a Zulu City, Studies in African Health and Medicine, 4. (Lampeter: The Edwin Mellen Press, 1990); G.C. Oosthuizen, Post-Christianity in Africa: A Theological and Anthropological Study. (Grand Rapids. MI: William B. Eerdmans Publishing Company, 1968); G.C. Oosthuizen (ed.) Religion Alive: Studies in the New Movements and Indigenous Churches in Southern Africa (Johannesburg: Hodder and Stoughton, 1986); H.W. Turner, History of an 
authors had a theological background and became increasingly sensitive towards the biblical foundation of the AICs. A case in point is the theologian G.C. Oosthuizen, who first introduced me to the field in South Africa. In PostChristianity in Africa: A Theological and Anthropological Study, ${ }^{4}$ he depicted a large number of the AICs as syncretistic movements which should be viewed as "new religions" built on magic, where the prophets took the place of God. Eighteen years later he edited the book Religion Alive, where he described the AICs in respectful terms as a valid response to the Bible that theologians should value and learn from as fellow Christians. ${ }^{5}$ Oosthuizen's later work seems to have been accepted by most theologians publishing on the topic.

The Pentecostal theologian Allan Anderson, ${ }^{6}$ for instance, has pointed out that theology, and in particular pneumatology - the doctrine of the spirit - has been a major source of tension between mission-based churches and the AICs, since the latter have tended to emphasize the work of the spirit to the exclusion of other doctrines. ${ }^{7}$ Another site of contention was that the work of the spirit was not an element of formal theology in the AICs but remained part of the religious practices and experiences. ${ }^{8}$ In his work on the Masowe Apostolics - the "Christians who don't read the Bible" - Engelke ${ }^{9}$ has convincingly argued that the imposition of colonial rule was largely attached to issues of literacy, and hence the movement was an expression of political resistance. ${ }^{10}$ The Bible, a Masowe pastor said, was written by "men with black hearts [and] is a record of what the Europeans want others to know."11 Despite these theological tensions Anderson has argued that practices related to the Holy Spirit largely overlap in the AIC and Pentecostal movements. This, he claimed,

African Independent Church: The Church of the Lord (Aladura) Vol. I. (Oxford: Oxford University Press, 1967); H.W. Turner, History of an African Independent Church: The Life and Faith of the Church of the Lord (Aladura) Vol. II (Oxford: Oxford University Press, 1967). Oosthuizen, Post-Christianity in Africa.

5 Oosthuizen, ed., Religion alive.

6 Allan Anderson, Moya: The Holy Spirit in an African Context (Pretoria: University of South Africa, Allan. 1991).

7 See also J.P. Mostert, "Men of 'the Spirit' or 'of spirit'?" in Religion Alive: Studies in the New Movements and Indigenous Churches in Southern Africa, ed. G.C. Oosthuizen (Johannesburg: Hodder and Stoughton, 1986).

8 See Turner, African Independent Church, vol II, 338.

9 Engelke, A problem of presence: Beyond scripture in an African Church. Edited by J. Robbins, The Anthropology of Christianity (Berkeley: University of California Press, 2007).

10 See Comaroff, Jean, and John L. Comaroff, Of Revelation and Revolution: Christianity, Colonialism, and Consciousness in South Africa, vol. I (Chicago and London: The University of Chicago Press, 1991), Chap. 6; Comaroff, Body of Power.

11 Matthew Engelke, Text and performance in an African church: The Book, "live and direct." American Ethnologist 31, no. 1, 2004, 78. 
constitutes a common biblical foundation, is not related to the AICs "preChristian past" and begs for mutual respect and dialogue. ${ }^{12}$ Though I think Anderson's approach and position in relation to the AICs is laudable, I partly disagree with the latter point, emphasizing in this chapter the continuities that exist between my Zulu Zionist informants' spiritual experiences and precolonial Zulu ritual practices. I use this perspective to suggest that pneumatology can be viewed as a result of a long-standing ritual relationship between Zulu people and what anthropologist Tim Ingold has coined the "weather-world."13

Before I proceed, a brief outline of the historical context of the AICs and the Zionist movement is required. I particularly focus on South Africa and the Zulu people, as this uncovers the historical foundation for the particular forms taken by encounters with spirits during my fieldwork.

\section{The Historical Backdrop}

Although the first secessions from the mission churches occurred on the Eastern Cape during the 1880 s, ${ }^{14}$ Barrett concluded that more than 50 per cent of the AICs originated among the Zulu people. ${ }^{15}$ These congregations had two sources: they either seceded from mission churches or emerged under African leadership from outside the churches, drawing on African traditions entering into dialogue with Christianity. ${ }^{16}$ The central role of the Zulu in these movements is often accounted for by referring to the sufferings and social changes imposed on the Zulu people in particular. ${ }^{17}$

The first decades of intense mission work in South Africa occurred in a century plagued by war, turbulence, and great social upheaval. It started with "the time of great unrest" (mfecane), which sent shock waves through southern Africa in response to Shaka Zulu's warfare. ${ }^{18}$ These violent demographic changes

For a noticeable exception see Joel Cabrita for an account of the Ibandla lama Nazaretha, often referred to as the Shembe Church Joel Cabrita, Text and Authority in the South African Nazaretha Church, (New York: Cambridge University Press, 2014).

12 Anderson, Moya, 6.

13 Tim Ingold, "Footprints through the weather-world: walking, breathing, knowing," Journal of the Royal Anthropological Institute 16, (2010), 121-139.

14 Sundkler, Bantu Prophets, 38.

15 Barrett, Schism and Renewal; See Daneel, Zionism and Faith-Healing, 9.

16 Barrett, Schism and Renewal, 110.

17 Ibid., 50.

18 See John Laband, Rope of Sand: The Rise and Fall of the Zulu Kingdom in the Nineteenth Century (Johannesburg: Jonathan Ball Publishers, 1995); Stephen Taylor, Shaka's Children: A History of the Zulu People (London: Harper Collins Publishers, 1994). 
were further stimulated by "the great trek" in 1836 , when the Boers, tired of interference from the British administration, moved inland and settled in the Orange Freestate and Transvaal, spurring further conflicts as they displaced African settlements from the areas they occupied. This was followed by the great mineral discoveries in the 1870 , which, among other things, resulted in the implementation of new tax laws in order to force African men into wage labor in the mines.

An independent Zululand had remained a constant factor of distress for the British settlers. The "excuse" to invade Zululand came after the crowning of King Cetshwayo in 1873, when he started a nationalistic policy of building up the army and a more centralized state, which restricted British interests. ${ }^{19}$ Several nineteenth-century missionaries considered the national pride of the Zulu a major obstacle to conversion and thus have been regarded as another factor behind the British invasion in 1879. This was resplendently exposed in an article in a Norwegian Missionary bulletin which noted: "To human eyes it looks as if this people only through material and political humiliation can be brought to their knees and taught to seek something higher."20

A year after the invasion the Zulu kingdom crumbled in the battle of Ulundi. Zululand was divided into thirteen provinces ruled by chiefs appointed by the British administrators and, in 1897 , fully incorporated into the British colony. Meanwhile, in the years following the Zulu war, the British were in continuous friction with the Boer republics. Foreign investors and traders moved into the mining areas and, as the struggle for control of the riches escalated, violence increased. Conflict with the Boers erupted yet again in 1899 when the Boer army attacked the Cape Colony, a war that ended with British victory in 1902. These wars inflicted great hardship on the African communities, killing a large percentage of the population and breaking descent and kinship ties as the people were uprooted and placed in camps scattered throughout the Natal midlands and Transvaal, without concern for lineage or clan affiliation.

With the introduction of The Natives Land Act of 1913 the African communities were effectively barred from owning land and sustaining a viable household. This caused further frustration and increased suffering in the African communities and the AICs emerged as a venue open for resistance towards

19 Jeff Guy, The Destruction of the Zulu Kingdom: The Civil War in Zululand 1879-1884, 1994 ed. (Pietermaritzburg: The University of Natal Press, 1975).

20 Norsk Misjons Tidene Feb. 1860, in Jarle Simensen, "Religious change as transaction: the Norwegian mission to Zululand, South Africa 1850-1906," in Religion, Development and African Identity, ed. K.H. Petersen (Uppsala, Sweden: Scandinavian Institute of African Studies: 1987), 89 . 
colonial rule. ${ }^{21}$ Sundkler clearly stated: "the separatist church problem is a corollary of the land problem," and moved on to quote an oft heard statement among African agitators: "at first we had the land, and you had the Bible. Now we have the Bible, and you have the land."22 There seems to be complete agreement among commentators that the exponential growth of the AICs started in the aftermath of the Natives Land Act. These developments had a particular bearing on the clan system. The clan was not only a central aspect of individual identity but harbored a particular significance for notions of health and wellbeing. As I will now argue, a good, prosperous life depended on the unity of the clan.

After the Native Land Act was implemented the once so proud Zulu, with their identity firmly entrenched in their famous clans and agnatic lineages, were uprooted and placed in an environment where their traditional network was weakened, cut off, or irrelevant to the social reality they experienced. This situation was aggravated by the fact that the missionaries had established a clear dividing line between Christians (amakholwa), and traditionalists (amakhonza). ${ }^{23}$ The division between these two camps in Zulu society was strict and it split the clans, with little contact across the religious divide. ${ }^{24}$ The mission practices ensured that conversion to Christianity implied a break with the non-Christian (khonza) fraction of the clan, a split that continued to affect the lives of my informants negatively in contemporary South Africa.

In order to illustrate this, I turn to my informant Thandi, who had some difficult and life-changing encounters with winds that were experienced as spiritual interventions in her life. I then moor these encounters in a historical understanding of ritual practices in which the split between the Christian and traditionalist Zulu society emerges as a source of misfortune. ${ }^{25}$ Finally I argue

21 Comaroff, Body of Power.

22 Sundkler, Bantu Prophets, 33.

23 Simensen, Norsk Misjon og Afrikanske Samfunn, 91-95; See also Rune Flikke, "Embodying the occult: religious experiences and ritual practices in urban Zulu Zionism," in The Power of the Occult in Modern Africa: Continuity and Innovation in the Renewal of African Cosmologies, ed. J. Kiernan (Berlin: Lit Verlag, 2006), 214. The literature mostly refers to the traditionalists as the amakholwa, whereas they were usually referred to as the amabhiwa during my fieldwork.

24 Absolom Vilakazi, Zulu Transformations: A study of the Dynamics of Social Change, (Pietermaritzburg: University of Natal Press, 1965).

25 Though this was the case in traditional Zulu practices (e.g. Axel Ivar Berglund, Zulu Thought Patterns and Symbolism (London and Cape Town: C. Hurst and Co. Ltd, 1989), 26o) the attribution of suffering to the work of ancestral spirits seems to vary within the AICs. In a study of Zionists close to my own field site, Jim Kiernan (Kiernan, Therapeutic Power) claimed that suffering was usually not ascribed to the work of ancestral spirits but 
that an analytical focus on the phenomenological connections between air and spirit can account for Thandi's spiritual experiences.

\section{Thandi: Suffering, Winds, and Spirits}

I met Thandi through the prophet Themba, who shortly before I started my first fieldwork had founded his own Zionist congregation in order to deal with some personal health problems he described as "asthma and chest pains." As will become apparent below, this was taken as a sign that his traditionalist ancestors wanted to have an influence on his otherwise Western and Christian life-style. Themba's congregation met at his house on Sunday mornings, though the most attended and anticipated service was held the first weekend every month, when we met on Saturday evening for an all-night "commemoration service for the departed." 26 The general picture that emerged from the illness narratives I collected was that the afflictions with which his patients struggled were related to violence, poverty, loneliness, and illnesses, and closely associated with African life in a violent, racist, apartheid state.

These generalized sufferings were spoken of as umnyama (darkness), and have strong connotations of illness and suffering. When I asked my informants what someone was suffering from, they would often describe the affliction as ubumnyama, a term Themba said was best translated as "walking in darkness." Though he often translated umnyama as "bad luck," the term described a state of being where the afflicted literally generated suffering. Thus ubumnyama was created by "dark" substances, which caused suffering for those "walking in darkness."27 It was therefore considered a "being-in-the-world" whereby the afflicted generated problems through their bodily presence. ${ }^{28}$ This could be caused by witchcraft or be the result of general environmental pollution, to which I return below. ${ }^{29}$

to witchcraft. During my fieldwork, both were very common explanatory models. The two were clearly distinguished but I often heard claims that if the ancestral spirits had been properly tended, they would have been able to protect the victim from witchcraft.

26 Rune Flikke, The Past in the Present: A Semiotic Exploration of Urban Zulu Zionism in Durban, South Africa. Cand. Polit, The Department and Museum of Anthropology, The University of Oslo, Oslo, Norway, 1994.

27 Flikke, "Embodying the occult" 228f.

28 Otto F. Raum, The Social Functions of Avoidances and Taboos Among the Zulu, Monographien zur Völkerkunde (Berlin and New York: Walter de Gruyter, 1973), 46off; Flikke, "Embodying the occult."

29 See also Rune Flikke, "Enwinding social theory: Wind and weather in Zulu Zionist sensorial experience," Social Analysis 6o, no. 3 (2016), 95-111. 
I had recently started my first fieldwork when I first met Thandi in Themba's office. She stood out from the rest of the people I had met there. She was elegantly dressed, would always greet me with a handshake, address me in fluent English, and look me squarely in the eyes. For most of my Zulu informants, this was not only rude and disrespectful behavior, but could also be associated with witchcraft since an invading gaze is an indication that you are out to control the recipient. Facing me as a Western man, however, she signaled that she was a sophisticated and liberated African woman who managed to navigate the two worlds. Thandi's education was impacted by the school boycotts that spread at an epidemic rate after the Soweto uprising of June 1976 but what she lacked in formal education, she compensated for through hard work and intelligence. When we were first introduced, she worked in the finance department of a large governmental institution.

Shortly after we met, she mentioned that she had started to abruptly fall asleep a while back. This often occurred at mid-day and she was unable to control it. While asleep she dreamt frightening dreams where she saw people she loved in pools of blood; she dreamt she was safe at home when blood started to seep in under her door and run down the walls of her house. At this time she also struggled with spates of uncontrollable hiccups and yawning. Within pre-colonial Zulu cosmology, these are significant developments. Dreams are messages from the ancestors and violent dreams like these are highly problematic. She therefore contacted a number of traditional healers (izangoma), who all told her the same story - somebody was out to harm her and she was in danger. Several claimed it was her mother who was trying to take control of her money because she was jealous of her daughter's success. Apparently, since Thandi had no father, her mother felt Thandi's income rightfully belonged to her until she was properly married. The dreams, she was told, were a sign that her mother was using witchcraft to establish that control.

As I have recounted elsewhere, ${ }^{30}$ Thandi experienced a brutal attack when five men forced their way into her home one night to kill her and use parts of her bodily organs in witchcraft remedies in order to transfer her "good luck" to the users. ${ }^{31}$ She lost her grip on the world after the attack. She fainted on a regular basis, was afraid to leave her house in the morning, and could not cope at work. It was during this time she contacted Themba. In a few short months he had got Thandi back on her feet and brought back the self-confidence which

$30 \quad$ Rune Flikke, "Thandis historie. Når tid, sted og kropp møtes," Norsk Antropologisk Tidsskrift 18, 3-4 (2007), 296-307; Flikke, Enwinding Social Theory.

31 See Isak Niehaus, Witchcraft, Power and Politics: Exploring the Occult in the South African Lowveld, Anthropology, Culture and Society (London: Pluto Press, 2001), 66. 
was so striking when I first met her. Soon after Themba started the treatment her dreams changed: from containing nightmarish images they were now filled with experiences of flying, wind, and water. One night, she told me, she woke from a dream with a feeling that her chest had opened up between her breasts and shoulder blades. A wind started blowing and created a draft through her upper torso. It throbbed so intensely that she was unable to sleep. She was awake the rest of the night. She added pensively that it had not been windy outside. The next day she was unable to work because of the pain. She immediately connected this experience with something that happened a while later. On this occasion she woke with a feeling she described as being repeatedly hit by a boulder. She bounced up and down in bed while she spoke English as well as in tongues.

I did not collect similar narratives from other informants. However, Thandi's experiences with winds were part of a larger cultural landscape connected to notions of the spirit and hence created no comment or reaction in the congregation beyond people's singling Thandi out as a spiritually gifted person. The literature, however, reveals a number of similar accounts. Sundkler recalled how an informant explained his conversion to Zionism by referring to an experience with a nocturnal wind: "I awoke. A sharp wind blew. I felt that I was full (ngisuthile), I was full indeed. I almost burst ... I fell down. I threw myself in all directions. My whole body was shaking ... I was perspiring and filled with uMoya."32 Furthermore, Themba's services were always accompanied by an endless flow of sneezing, belching, groaning, and whistling sounds that emphasized the unusual and irregular movement of air during periods of the services when the Spirit moved. ${ }^{33}$

In order to understand this particular ritual behavior there is a need to take a closer look at spirits in the Zulu conceptual universe, as well as investigating more closely pre-colonial and traditional ritual practices.

Wind, Breath, and Spirit in Zulu Religious Practice

In Zulu cosmology, the person consists of three parts: first, umzimba, which is the physical body; second, isithunzi, which literally means the "shadow" of an

32 Sundkler, Bantu Prophets, 245. Umoya usually refers to spirit, wind, or breath. The term will be discussed in more detail in the next section.

33 See B.A. Pauw, Religion in a Tswana Chiefdom (London: Oxford University Press, 1960), 200. 
object or person and is the spirit in the living, which forms part of the ancestral spirit $(i d l o z i)^{34}$ after death. Idlozi is philologically related to umlozi, the spirit of a necromancer made audible as a whistling sound and hence associated with winds. The missionary Axel-Ivar Berglund - who was born and raised and then worked in the mission field in Zululand, and spent time as a member of the South African Council of Churches - stated that isithunzi is the preferred term for spirit among the Traditionalists. ${ }^{35}$ The third term, which is my main concern here, is umoya, which refers to spirit, soul, air, wind, and breath. ${ }^{36}$ Umoya is the vital force of humans and, once it leaves, the body stops breathing and is dead. Then people say "umphefumelo, i.e. the air, the breath, or the spirit has left the body and the person is no more." ${ }^{37}$ The Catholic missionary A.T. Bryant argued that, historically, umoya should only be translated as breath, wind, and air but that the term was also used by early missionaries as a translation for the biblical concept of soul and spirit. ${ }^{38}$ Berglund's discussion supports Bryant, claiming that umoya most probably was given emphasis by Christian missionaries and hence primarily refers to the Holy Spirit. ${ }^{39}$ Though I think this is very likely, I have elsewhere argued that Zulu history indicates a longstanding connection between ritual practices and wind, air, and atmosphere. ${ }^{40}$ The translation of umoya as spirit would hence make sense in relation to traditional ritual practices. Furthermore, in Themba's congregation the Holy Spirit was specifically referred to as umoya ongcwele (pure and holy). ${ }^{41}$ In the following I therefore focus on the continuities between Christian and pre-colonial Zulu cosmology and ritual practice.

In order to stress the common ground between the traditional and Christian notions of the spirit, I will now connect Thandi's encounter with the spiritual realm and winds - umoya - to a long-standing ritual relation between the spiritual and the weather-world. David Livingstone's account of his interaction

34 For a more thorough discussion of idlozi see Berglund, Zulu Thought Patterns, 89ff.

35 Ibid., 85 .

36 The KiKongo term moyo, translated as "soul" or "life force" by Janzen, see John M. Janzen, The Quest for Therapy: Medical Pluralism in Lower Zaire (Berkeley and London: University of California Press, 1978), 179, note 7. It was discussed in the same context as breath (ibid., 175) and dizziness (ibid., 177).

37 Vilakazi, Zulu Transformations, 87.

38 A.T. Bryant, Zulu-English Dictionary (Pietermaritzburg: Davis, 1905), 392.

39 Berglund, Zulu Thought Patterns, 85.

$40 \quad$ Flikke, Enwinding social theory.

$41 \quad$ Cwe can be translated as "clear," "transparent," or "bright" and has been adopted by the Catholic Church to depict a holy person or saint, see Harriet Ngubane, Body and Mind in Zulu Medicine: An Ethnography of Health and Disease in Nyuswa-Zulu Thought and Practice (London and New York: Academic Press, 1977), $118 f$. 
with the Kwena rain doctor indicates that the weather has been a point of contention since the first contacts between European missionaries and the populations of southern Africa. In Livingstone's account the rain doctor presented a cosmos in which humans were firmly embedded in the weather-world, possessing the ability to influence, as well as be influenced by, the weather. ${ }^{42}$ Similar links between people and the weather-world are also apparent within the contemporary Zionist movement.

\subsection{Air, Wind, Health, and Misfortune}

Vicious thunderstorms are a regular occurrence in KwaZulu-Natal. Lightning is naturally feared for its power to kill, but is also perceived as "heat" from the "Lord-of-the-Sky." It is said to be a result of his anger (inthukuthelo) and a physical manifestation of power (amandla). Mountains are struck relatively often by lightning and hence become infused with spiritual power from the Lord-ofthe-Sky. As I will outline briefly below, environmental pollution, as an aspect of material substance, is both a source of health and disease. ${ }^{43}$ The association between mountaintops and lightning ensures that mountaintops are sought out as places of worship, healing, and restoration, ${ }^{44}$ yet they are also potentially polluting places due to "tracks" the lightning leaves behind. ${ }^{45}$ Therefore ritual places should be approached with caution. Therefore, Themba would only lead us up to the cairn at the highest mountain near his house for the night-long commemoration service for the departed after an elaborate cleansing ritual.

In Zulu cosmology, all substances have metaphysical qualities. As we move through the landscape, some of our substances are shed and left behind and others are picked up. ${ }^{46}$ These are the tracks (umkhondo) that dogs detect while hunting, a belief that is a cultural trait shared with the neighboring Khoisan. ${ }^{47}$ As mentioned above, diseases were mostly spoken of as umnyama (darkness) ${ }^{48}$ caused by pollution, and whenever people or cattle crossed tracks left by

42 David Livingstone, Missionary Travels and Researches in South Africa (London: J. Murray, 1857), 23-25.

43 For a more thorough discussion of this notion of pollution as an aspect of material substances, see Berglund, Zulu Thought Patterns, 256ff. Rune Flikke, "Writing 'naturecultures' in Zulu Zionist healing," Nordic Journal of Science and Technology Studies 2, 1 (2014) 13f; Raum, Social Functions of Avoidances, 46off.

44 Ngubane, Body and Mind in Zulu Medicine, 25.

45 Vilakazi, Zulu Transformations, 24f.

46 Ngubane, Body and Mind in Zulu Medicine, 24ff.

47 Chris Low, "Khoisan wind: hunting and healing," Journal of the Royal Anthropological Institute (N.S.) 13, no. 1 (2007), 75 .

48 Flikke, "Embodying the occult," 211ff. 
humans or animals associated with umnyama, they were exposed to defiling forces that would eventually make them sick unless they were properly cleansed and strengthened through ritual means. ${ }^{49}$ The tracks can also float in the air as "threads" that connect people and places. ${ }^{50}$ In this case they are spoken of as imimoya (plural of umoya). Imimoya can be inhaled, and if these aerial threads are defiling (imimoya emibi) they will pollute and result in disease. ${ }^{51}$ These tracks become particularly troublesome in large cities, plagued both by pollution and an abundance of people. ${ }^{52}$

As Janzen has convincingly argued, ritual practices are dominated by affinities across Africa's Bantu speaking populations. ${ }^{53}$ In this context it is worth noticing that Monica Wilson gave similar accounts of the close connection between winds, illnesses, and destruction among the Bantu speaking Nyakusa. "The witches," she wrote, "fly by night on their pythons, or 'on the wind." 54 In this context, the wind transports the witches and their evil deeds, thereby spreading disease and devastation. The air could also be a medium through which witchcraft (ubuthakathi) was spread. The culprit, Adam Ashforth ${ }^{55}$ informed us in a study of witchcraft in Soweto, could hold the witchcraft remedies in the palm of his hand and blow the powdered substance into the air to be carried away by the winds, tracking down and striking the victim.

The presence of witches and their evil deeds could not be seen, but rather sensed in the air. The Zulu "witch finders," Krige wrote, "smelled out" [ukubula] the witches. As he danced towards the suspects, he "examine[s] them by means of his olfactory sense," ${ }^{25}$ following the threads in the air left behind by the evil doers. The perception of witchcraft as a substance of a negative, forceful, and dark appearance therefore has certain olfactory qualities. This finds a parallel

49 William Beinart and Karen Brown, African Local Knowledge and Livestock Health:Diseases and Treatments in South Africa (James Curry: Woodbridge and Rochester, NY, 2013), $210 f f$.

5o Tim Ingold, Being Alive: Essays on Movement. Knowledge and Description (London and New York: Routledge, 2011), 121.

$5^{1} \quad$ Ngubane, Body and Mind in Zulu Medicine, 24ff.

$5^{2}$ See Flikke, Enwinding social theory, 102.

53 John M. Janzen, "Ngoma: Discourses of Healing in Central and Southern Africa," in Comparative Studies of Health Care Systems and Medical care, eds. J.M. Janzen and C. Leslie, (Berkeley, Los Angeles and Oxford: University of California Press, 1992).

54 Monica Wilson, Good Company: A Study of Nyakusa Age-Villages (Prospect Heights, Ill: Waveland Press, Inc, 1951), 91.

55 Adam Ashforth, Madumo: A Man Bewitched (Chicago: University of Chicago Press, 200o), 126.

$5^{6}$ Eileen Jensen Krige, The Social System of the Zulus. $195^{\circ}$ ed. (Pietermaritzburg: Shuter and Shooter. 1936), 225 . 
in Khoisan notions of both wind and witchcraft, ${ }^{57}$ as well as in the coastal areas of East Africa, where Parkin has argued it is because smell "wafts on the wind that it is of crucial importance" in ritual contexts. ${ }^{58}$

Winds carry dust, smoke, and odors, thus weaving perceptible, defiling threads through the atmosphere - threads that connect people and places in ways that cross time and space, potentially bringing humans in touch with substances from places associated with pollution and disease as well as wellbeing. These atmospheric threads can have detrimental influences on those exposed. Yet not only substances float in the air. Sounds do as well. I have elsewhere accounted for how "bird-talk" and chirping were of spiritual importance. ${ }^{59}$ These sounds float in the air, bringing subjects in contact with distant people, places, and spirits. These auditory aspects of air are essential for the creation of a ritual atmosphere.

\subsection{Winds and the Sound of Spirits}

Mountaintops and coastlines, favored locales for Zulu Zionist ritual activities, are open spaces of contact characterized by their exposure to winds. The winds at these locations would interact with the surroundings, speaking as they whistled over the crags or mingled with the sounds of the waves pounding the shoreline, carrying sounds from afar and, at times, drowning the voices of those standing next to you. These whistling sounds permeated the ritual processes, not only a result of interactions between wind and landscapes but also of the spirits taking hold of, and filling the bodies of the participants.

In this context it is interesting that the Nyakyusa word for "witch" (abalozi) means "the one that travels with the wind." 60 This is the same word the Zulu use for the practice of divination in which the diviner (isangoma) sits in umsamo, the place where the ritual artifacts of a household are stored, and interprets whistling sounds coming from ikhothamo, the sacred area in the thatching at the back of the hut. ${ }^{61}$ These are the voices of the spirits and, in these divination practices, the wind whispering around the huts carries messages from the ancestors. I claim that the same messages from the same source are heard when the wind interacts with the landscape, filling the hollows of the ground with sounds as it blows through valleys, whistling as it grabs hold of mountains and caverns. The presence of the ancestral spirits - in this context referred to as the

57 Low, Khoisan wind.

$5^{8}$ David Parkin, "Wafting on the wind: smell and the cycle of spirit and matter," Journal of the Royal Anthropological Institute (N.S.) 13, no. 1 (2007), 41.

59 See Flikke, Enwinding social theory.

6o Wilson, Good Company, 91.

61 See Berglund, Zulu Thought Patterns, 119. 
abaphansi (those down below) ${ }^{62}$ - was also sought in canyons, by waterfalls, and in caves. These are permeable places, openings to the ancestral world below, and filled with the auditory presence of the unseen. These sounds make the places come alive, filling the air with the audible presence of the ancestors.

In a similar vein Terence Ranger has accounted for how the inaccessible Matopos, south-west of Bulawayo, with its "wild granite hills with narrow gorges" 63 was a traditional spiritual center for the oracular cult of the High God, Mwali. Quoting a letter dated 28 March, 1880, he described the area as a place where:

God lives in a subterranean cave in a labyrinth of rocks ... In this cave is a deep, black well, the well of the abyss. From time to time dull sounds like thunder come forth from this well. The faithful ... seek information about hidden things, future happenings, the names of people who have bewitched them. ... After a few moments of deep silence, they hear, in the midst of the subterranean noises, inarticulate sounds, strange words, broken and incomprehensible. ${ }^{64}$

These relations between the realm of the spirits, landscapes, and movement in the weather-world were not articulated in Themba's congregation other than through testimonies such as that given by Thandi. However, when the spirit (umoya) swirled amongst the ritual participants as the wind (umoya) interacted with the ritual landscape, those possessed by the spirit would emit whistling sounds, grunt, yawn, and in other ways respond by audible changes in the respiratory functions, demonstrating that bodies, just like landscapes, are permeable and interact with umoya. These events were an integral part of the ritual life in Themba's congregation, hence an aspect of the habitus and best elicited as unreflexive bodily engagement with the world which indicated the presence of non-Christian ancestral spirits (amadlozi).

I have thus argued that Thandi's spiritual encounters should be interpreted as cultural and historical adaptions to exposure to the weather-world. The question that remains to be addressed is how we can theoretically account for

62 There are many different terms used to refer to ancestral spirits. The most common among my Zionist informants was abadala (the old ones). The amadlozi discussed above were mostly reserved for non-Christian ancestral spirits.

63 Terence O. Ranger, Voices from the Rocks: Nature, Culture and History in the Matopos Hills of Zimbabwe (Oxford: James Currey, 1999), 11.

64 Ibid., 15. 
these connections while outlining some cross-fertilization that might occur when theological and anthropological understandings enter into dialogue.

\section{$5 \quad$ Weather, Perception, and the Open Body}

The winds at the mountaintop I climbed with Thandi and the other participants in Themba's congregation the first Sunday of every month howled over the landscape and grasped hold of our bodies. We bent over, flexing our muscles to withstand its force. On these occasions the bodies of the afflicted took shape from the will to resist the power of the wind. The force and lightness of the wind shaped the force of the spirit. The two are not only signified by the same word, umoya, they were both haptically present when the winds touched the afflicted at these places of worship, physically challenging them to rise, stand, lean against its force, and move forward. These were bodily motions that, I started to notice, influenced the ritual atmosphere, as the participants were gradually invigorated and filled with the lightness of the air and spirit as we approached the summit. ${ }^{65}$ Thandi's particular encounters with the weatherworld make further sense once we look at relations between bodies and the winds of umoya.

As discussed above, the threads in the air (immimoya) reflect a tradition in southern Bantu thought that perceives winds as sources of both disease and health. Bryant noted that for the Zulu, the common cold (umkuhlane) was brought by the winds; certain winds were therefore threats to health and avoided when possible. ${ }^{66}$ Thandi's accounts brings to the fore a different connection between winds and wellbeing. The winds she encountered caused stabbing pains as her upper body was opened and filled with umoya. The fact that the stabbing took the form of wind blowing through her torso suggests a strong connection between wind and the pain. This is confirmed by historical sources; the sensation of a cavity opening in the abdomen is well known and described in the ethnographic studies of the Zulu peoples from the early nineteenth century onward. The pioneer missionary Callaway, for example, accounted for symptoms similar to those Thandi experienced when he referred to a phenomenon called uthlabo, from the verb ukuhlaba (to stab). He wrote:

65 See Gaston Bachelard, Air and dreams: an essay on the imagination of movement. First French edition, 1943 ed, The Ballard Translations (Dallas, TX: Dallas Institute Publications, 1988), 156.

66 A.T. Bryant, Zulu Medicine and Medicine-Men, reprint, 1983 ed. (Cape Town: Centaur, 1983);: Cabrita, Text and Authority, 17. 
Uthlabo is known by causing a sensation of perforation of the side; and the man says, 'I have pain under the armpit, beneath the shoulder blade, in my side, in the flesh. It causes the feeling as if there was a hole there; the pain passes through my body to each side.'67

This was an illness that could have a natural cause and be treated with the traditional herbal medicine umuthi. However, if it persisted after treatment, the ancestral spirits were causing it by "walking in the person,"68 a sign that the person had a call to become a diviner. In light of the above account of Thandi's experiences it becomes apparent why she had a central position as a prayer lady in the church. Callaway further informed us that the successful treatment of uthlabo would make the illness diminish because "his people [ancestors] are in him. They wish him to dream." ${ }^{\prime 9}$ Dreams are the primary way of communicating with the ancestral spirits and - since protection and guidance from the ancestors is essential for a good and prosperous life - of vital importance. Furthermore, dreams are directly connected to pains in the shoulders and upper body, since these spots are the places where the ancestors can make themselves felt. ${ }^{70}$

The stabbing nature of Thandi's encounters with winds was also the result of being compromised and opened by metaphysical forces that merged her fate with the metaphysical qualities of the substances the winds carried. Despite the pain, her experiences were positive; winds entering through the chest indicate positive ancestral intervention. Pain in the chest and shoulder blades is a sign of ancestral presence in the afflicted since the chest and upper back is "the place they occupy in a man."71 These experiences were accompanied by vivid dreams and water, which were associated with the flight and movement of the spirits and cleansing properties of water.

I am suggesting that it is not enough to approach these phenomena as symbols and cultural thought-patterns, but, rather, that they are haptic engagements with the weather-world and need to be approached as ontologies. However, that raises the question of how culturally specific historical developments have influenced our engagements with the weather-world. ${ }^{72}$

$67 \quad$ Henry Callaway, The Religious System of the Amazulus, Africana Collectanea Volume xxxv, facsimile reprint, 1970 ed. (Pietermaritzburg: Davis and Sons, 1868), 268.

68 Ibid.

69 Ibid., 270.

70 Berglund, Zulu Thought Patterns, 98.

71 Ibid., 115 .

72 See Oliver J.T. Harris, John Robb, and Sarah Tarlow, "The body in the age of knowledge," in The body in history: Europe from the Palaeolithic to the future, eds. J. Robb and O.J.T. Harris (New York: Cambridge University Press, 2013), 167. 
Tim Ingold is one prominent social theorist who has pondered why weather has been so understudied. ${ }^{73}$ The reason for this lack of analytical investigation, he argues, is that since Descartes the Western world has increasingly conceived of life as existing on the external surface of the globe, thus turning humans into "exhabitants" who are composites of body and mind, residing in a world of matter and a world of ideas respectively. ${ }^{74}$ In this world of increasingly separate and labeled objects and subjects, the ground under our feet became the source of stability and the material subsistence requirement for life, while the atmosphere retreated to become a passive backdrop against which mobility, and olfactory, visual, and auditory perception occurred. In this modernist understanding of nature, the surface of the landscape marks the limit of materiality and the air is for the most part conceived of as immaterial - an empty space that enables the interaction between human subjects and material objects. ${ }^{75}$ In short, we have an ontology that prioritizes surface over medium, and thus misrepresent the intermingled relationship between bodies and the air.

Ingold suggests that we should turn this ontology on its head and treat the world as consisting of earthly substances and an aerial medium in which we are immersed. ${ }^{76}$ Thus, rather than taking the landscape as the surface on which human activities are played out, we should view weather and the earth's atmosphere as the central medium through which most human actions occur. This reversal creates a world where human life, rather than being founded on solid, stable earth, emerges as spun on "a fragile ephemeral raft,"77 thereby tying human experience closer to fluidity, flux, transformations, and transience, which indeed are at the core of spiritual experiences. As such, the ontological reversal Ingold suggested promises to place flux, emergence, and change in the midst of social theory, a course which fits well with the fact that air is the foundation of our existence. Without air and breath there is no life. In line with Ingold's argument, we could therefore say with Robert Chapigny that, "air is breathing rather than what a body breathes." 78

The weather-world is hence the medium through which humans perceptually engage with the external world and thus has the capacity to influence

73 E.g. Tim Ingold, "The eye of the storm: visual perception and the weather," Visual Studies 20, no. 2 (2005), 97-104; Tim Ingold, "Earth, sky, wind, and weather," Journal of the Royal Anthropological Institute (N.S.) 13, no. 1 (2007), 19-38; Tim Ingold, Being Alive: Essays on Movement. Knowledge and Description. (London and New York: Routledge, 2011), Part 3.

74 Ingold, Being Alive, 116.

75 Ingold, Eye of the Storm, 103.

76 Ingold, Being Alive,116.

77 Ingold, Eye of the Storm, 103.

78 Bachelard, Air and dreams, ix. 
perception of, and engagements with, the world as emergent process. Air then, is inseparable from life and consubstantial with the sensing body as our "setting in relation to the world." ${ }^{\prime 9}$ Consequently the weather-world has the capacity to "affect the whole of consciousness." ${ }^{\text {" To }}$ The "lightness" and "thinness" of air is the essence of life that enables movement.

Within this interpretive framework Thandi's oneiric flights are clearly joyful dreams of lightness, freedom, new possibilities, upliftment, and growth. ${ }^{81}$ They were encounters that literally "enwinded" her, reinstating her as an acting subject in charge of her own destiny.

\section{Umoya and Life in the Weather-world}

In Zulu culture the ancestral spirits are venerated through small everyday practices as well as through more elaborate ritual sacrifices. ${ }^{82}$ They are considered to be omnipresent and, as the elders of the clan, they have influence over their descendants. The ancestral spirits have kept their way of life and personal traits, and therefore appreciate being shown respect by being served their favorite food and having their favorite hymns sung during the altar service (ilathi) conducted at most ritual gatherings. As mentioned above, afflictions were commonly and explicitly taken to be signs that traditional ancestral spirits were objecting to a Christian life style. Such expressions of anger (inthukuthelo) were considered to be acceptable ways on the part of both God and ancestral spirits of responding to wrong-doing, ${ }^{83}$ and a central tenet in most ritual activities I encountered during my fieldwork. Themba's healing rituals aimed at accommodating both Christian and non-Christian ancestral spirits and showing the latter respect through the adaptation and adoption of some of their ritual practices as well as idiosyncratic traits.

Though the literature points out that the roots of Zulu Zionism are to be found in the Pentecostal movement, ${ }^{84}$ Themba, Thandi, and the large majority of the regular attendants at Themba's church services came from mission churches which sanctioned involvement with ancestral spirits. The result was that the historical split between the kholwa and the khonza surfaced as an

79 Maurice Merleau-Ponty, Phenomenology of Perception, trans C. Smith, English translation, 1962 ed. (London: Routledge and Kegan Paul, 1962), 303.

8o Ibid, 136 .

81 See Bachelard, Air and dreams, $33^{f}$.

82 E.g. Raum, Social Functions of Avoidances.

83 Berglund, Zulu Thought Patterns, $248 \mathrm{ff}$.

84 Anderson, Moya; Sundkler, Zulu Zion. 
explanatory source whenever my informants experienced a serious or prolonged period of illness and misfortune. Thandi repeatedly said that she was ambiguous about Zionism because it was laborious, time consuming, and costly. She said that she came to Themba and the Zionists to be healed through a ritual process whose aim was to mend the rift between the amakholwa and amakhonza and hence restore the unity of the clan as the source of a good and prosperous life. Once that was achieved, she hoped to return to the Anglican Church and what she often expressed as a "modern lifestyle." One final story will illustrate my point.

Mrs Xaba was a Christian healer following in the footsteps of her Christian grandfather, also a healer. After years of successful practice, she started to experience afflictions which signified an unbalanced relation with traditional spiritual powers. Themba brought Mrs Xaba through a cleansing ritual and held an ilathi service for her. She responded to the treatment by belching, groaning, and sneezing, which Themba interpreted as an indication of disharmony between the spiritual influence of the amakhonza and amakhol$w a$, because he conceived it to be a traditional response to a Christian healing process. In an effort to recreate the harmony, Themba told her to go through an amagobongo ${ }^{85}$ process to "balance" the traditional influences with the Christian, thus catering for the non-Christian ancestral spirits who were the source of her difficulties. Before she finished the process, however, her Christian grandfather - the most powerful of the ancestors - appeared in a dream telling her to stop the amagobongo process, which she did. A while later she received yet another dream where she saw herself walking along the road with a Bible under her arm. She was followed by three men of whom one was dressed as a traditional diviner, isangoma, whereas the other two were dressed in suits which, Themba emphasized, signified their Christian belonging. She started preaching to these men as they walked. Then she heard the men in suits say, "We have given her this power. She is powerful, so we must follow her." A lively discussion between the two men in suits and the isangoma followed. Then, all of a sudden, the isangoma was wearing a suit as well.

Themba said the interpretation was obvious. The isangoma had been converted in the hereafter through the ritual persuasion and sacrifices which asked him to accept his child's Christian life style and healing practice. He further emphasized that the spiritual power of Mrs Xaba, which now incorporated that of the converted isangoma, was even more potent than before because the traditional power had been redirected into the "Christian stream." This

85 Amagobongo is a traditional ritual process, which received its name from the calabashes used to mix herbal medicine umuthi. The aim of the process is to strengthen the traditional spiritual power in a person. 
would be very helpful in her treatment of people with spiritual problems that had a traditional root, because the traditional knowledge and the spiritual power of the converted isangoma were now integrated into her Christian healing. Subsequent to this dream, Mrs Xaba again pursued her Christian healing without encountering further disharmony.

\section{$7 \quad$ Conclusion}

In this chapter I have argued that mission history is essential to understanding the growth of the AICs in general, and the contemporary ritual dynamics within the South African Zulu Zionist movement in particular. The mission practice of sanctioning contact between the kholwa and khonza lay at the core of the illness narratives I collected over the three years I worked with Themba. When poverty, urban violence, and disease threatened the wellbeing of my informants, the lack of unity within the clan surfaced as a perpetual source of worry. The appeal of the Zionist movement is to be found in this historical gap. As the case with Mrs Xaba illustrates, the disputes between Christian and nonChristian ancestral spirits were still experienced as a barrier to the creation of the harmony conceived to be essential for the establishment of a good, prosperous life. Only after Mrs Xaba negotiated a ritual space where her dual heritage was recognized and her traditional ancestor accepted her Christian way of life was her health restored, allowing her to continue her Christian healing practice while also recognizing her Zulu heritage. In light of this outcome and those similar to it I claim that the spiritual encounters we witness in the Zionist movement should be approached through culturally and historically grounded studies.

In the southern Bantu cultures, where elders are respected and the ancestral spirits provide guidance and protection for the living, the rift created between the kholwa and khonza constitutes an existential insecurity, although it has been a central concern for me to argue that this understanding is not enough to account for the social dynamic of the vibrant Zionist churches. Thandi considered herself to be an Anglican, and she wanted to return to the Anglican Church. Her participation in Themba's congregation was not primarily to be understood as a question of faith but, rather, as a way to come to terms with her somatic responses to the traumatic attack. Her suffering brought her in contact with winds that surprised her. Her body was literally "enwinded" in ways that paved the route to healing and restoration. ${ }^{86}$ We therefore need to account theoretically for the fact that the body constitutes a surface that

See Flikke, "Embodying the occult." 
continuously interacts with the atmosphere that surrounds us and, in MerleauPonty's phenomenological approach, constitutes a setting in relation to the weather-world.

I approached this by first outlining historical material that revealed an intimate relation between winds and the landscape. Places where the interaction between wind and landscape has come to life have a long-standing significance in the ritual practices of southern Bantu peoples and their engagements with the spirit world. The winds touching the surfaces of the landscape created haptic and auditory relations with the realm of the ancestral spirits. Juxtaposing these practices with current Zionist practices, I suggest that we have a lot to gain from theoretically approaching the human body as a surface that is shaped in its interaction with the weather-world. By taking this ontological aspect of human life seriously, Thandi's case illustrates a profound aspect of human sensory engagement with the weather-world. The ephemeral touch of the wind, the haptic and auditory presence through the rituals, and the human inability to contain and control these forces are potentially spiritual and deeply existential experiences.

The winds Thandi encountered not only made the landscape come alive with sounds that were interpreted as messages from the spirits, they also physically blew through her body, as through the caverns and caves of the landscape, filling her with pain, but also enough life to counter the negative effects of the violent attack she and her family had undergone. It was an emotionally charged, restorative, and life changing experience which put her back on her feet after a highly traumatic event. This ability to engage practically with the predicaments of African life in a society that is still experienced as racist and exploitative by a large proportion of its members is essential for the appeal this movement has, even for individuals like Thandi, whose upward mobility is a product of her intelligence and hard work.

\section{References}

Anderson, Allan. Moya: The Holy Spirit in an African Context. Pretoria: University of South Africa, 1991.

Ashforth, Adam. Madumo: A Man Bewitched. Chicago: University of Chicago Press, 2000.

Bachelard, Gaston. Air and dreams: an essay on the imagination of movement. First French edition, 1943 ed, The Ballard Translations. Dallas, TX: Dallas Institute Publications, 1988. 
Barrett, David B. Schism and Renewal in Africa: An Analysis of Six Thousand Contemporary Religious Movements. Nairobi: Oxford University Press, 1968.

Beinart, William, and Karen Brown. African Local Knowledge and Livestock Health: Diseases and Treatments in South Africa. James Curry: Woodbridge and Rochester, NY, 2013.

Berglund, Axel-Ivar. Zulu Thought Patterns and Symbolism. London and Cape Town: C. Hurst and Co. Ltd, 1989.

Bryant, A.T. Zulu-English Dictionary. Pietermaritzburg: Davis, 1905.

Bryant, A.T. Zulu Medicine and Medicine-Men. Reprint, 1983 ed. Cape Town: Centaur, 1909.

Cabrita, Joel. Text and Authority in the South African Nazaretha Church. New York: Cambridge University Press, 2014.

Callaway, Henry. The Religious System of the Amazulus. Africana Collectanea Volume XXXV, facsimile reprint, 1970 ed. Pietermaritzburg: Davis and Sons, 1868.

Comaroff, Jean. Body of Power, Spirit of Resistance: The Culture and History of a South African people. Chicago and London: University of Chicago Press, 1985.

Comaroff, Jean, and John L. Comaroff. Of Revelation and Revolution: Christianity, Colonialism, and Consciousness in South Africa. Vol. 1. Chicago and London: The University of Chicago Press, 1991.

Daneel, Marthinius L. Zionism and Faith-Healing in Rhodesia. The Hague: Mouton and Co, 1970 .

Engelke, Matthew. Text and performance in an African church: The Book, "live and direct." American Ethnologist 31, no. 1 (2004):76-91.

Engelke, Matthew. A problem of presence: Beyond scripture in an African Church. Edited by J. Robbins, The Anthropology of Christianity. Berkeley: University of California Press, 2007.

Flikke, Rune. The Past in the Present: A Semiotic Exploration of Urban Zulu Zionism in Durban, South Africa. Cand.Polit, The Department and Museum of Anthropology, The University of Oslo, Oslo, Norway, 1994.

Flikke, Rune. Embodying the occult: religious experiences and ritual practices in urban Zulu Zionism. In The Power of the Occult in Modern Africa: Continuity and Innovation in the Renewal of African Cosmologies, edited by J. Kiernan. Berlin: Lit Verlag, 2006.

Flikke, Rune. Thandis historie. Når tid, sted og kropp møtes. Norsk Antropologisk Tidsskrift 18, no. 3-4 (2007): 296-307.

Flikke, Rune. Writing "naturecultures" in Zulu Zionist healing. Nordic Journal of Science and Technology Studies 2, no. 1 (2014): 12-18.

Flikke, Rune. Enwinding social theory: Wind and weather in Zulu Zionist sensorial experience. Social Analysis 6o, no. 3 (2016): 95-111. 
Guy, Jeff. The Destruction of the Zulu Kingdom: The Civil War in Zululand 1879-1884. 1994 ed. Pietermaritzburg: The University of Natal Press, 1975.

Harris, Oliver J.T., John Robb, and Sarah Tarlow. The body in the age of knowledge. In The body in history: Europe from the palaeolithic to the future, edited by J. Robb and O.J.T. Harris. New York: Cambridge University Press, 2013.

Ingold, Tim. The eye of the storm: visual perception and the weather. Visual Studies 20, no. 2 (2005): 97-104.

Ingold, Tim. Earth, sky, wind, and weather. Journal of the Royal Anthropological Institute (N.S.) 13, no. 1 (2007): 19-38.

Ingold, Tim. Footprints through the weather-world: walking, breathing, knowing. Journal of the Royal Anthropological Institute 16, supplement s1 (2010): 121-139.

Ingold, Tim. Being Alive: Essays on Movement. Knowledge and Description. London and New York: Routledge, 2011.

Janzen, John M. The Quest for Therapy: Medical Pluralism in Lower Zaire. Berkeley and London: University of California Press, 1978.

Janzen, John M. Ngoma: Discourses of Healing in Central and Southern Africa. Edited by J.M. Janzen and C. Leslie, Comparative Studies of Health Care Systems and Medical care. Berkeley, Los Angeles and Oxford: University of California Press, 1992.

Kiernan, Jim P. The Production and Management of Therapeutic Power in Zionist Churches Within a Zulu City, Studies in African Health and Medicine, 4. Lampeter: The Edwin Mellen Press, 1990.

Krige, Eileen Jensen. The Social System of the Zulus. $195^{\circ}$ ed. Pietermaritzburg: Shuter and Shooter, 1936.

Kuper, Adam. South Africa and the Anthropologist. London and New York: Routledge and Kegan Paul, 1987.

Laband, John. Rope of Sand: The Rise and Fall of the Zulu Kingdom in the Nineteenth Century. Johannesburg: Jonathan Ball Publishers, 1995.

Livingstone, David. Missionary Travels and Researches in South Africa. London: J. Murray, 1857 .

Low, Chris. Khoisan wind: hunting and healing. Journal of the Royal Anthropological Institute (N.S.) 13, no. 1 (2007): 71-90.

Merleau-Ponty, Maurice. Phenomenology of Perception. Translated by C. Smith. English translation, 1962 ed. London: Routledge and Kegan Paul, 1962.

Mostert, J.P. Men of "the Spirit" or "of Spirit"? In Religion Alive: Studies in the New Movements and Indigenous Churches in Southern Africa, edited by G.C. Oosthuizen. Johannesburg: Hodder and Stoughton, 1986.

Ngubane, Harriet. Body and Mind in Zulu Medicine: An Ethnography of Health and Disease in Nyuswa-Zulu Thought and Practice. London and New York: Academic Press, 1977. 
Niehaus, Isak. Witchcraft, Power and Politics: Exploring the Occult in the South African Lowveld, Anthropology, Culture and Society. London: Pluto Press, 2001.

Oosthuizen, G.C. Post-Christianity in Africa: A Theological and Anthropological Study. Grand Rapids. MI: William B. Eerdmans Publishing Company, 1968.

Oosthuizen, G.C., ed. Religion Alive: Studies in the New Movements and Indigenous Churches in Southern Africa. Johannesburg: Hodder and Stoughton, 1986.

Parkin, David. Wafting on the wind: smell and the cycle of spirit and matter.Journal of the Royal Anthropological Institute (N.S.) 13, no. 1 (2007): 39-53.

Pauw, B.A. Religion in a Tswana Chiefdom. London: Oxford University Press, 1960.

Ranger, Terence O. Voices from the Rocks: Nature, Culture and History in the Matopos Hills of Zimbabwe. Oxford: James Currey, 1999.

Raum, Otto F. The Social Functions of Avoidances and Taboos Among the Zulu, Monogaphien zur Völkerkunde. Berlin and New York: Walter de Gruyter, 1973.

Simensen, Jarle. ed. Norsk Misjon og Afrikanske Samfunn: Sør-Afrika ca. 1850-19oo. Trondheim: Tapir, 1984.

Simensen, Jarle. Religious change as transaction: the Norwegian mission to Zululand, South Africa 1850-1906. In Religion, Development and African Identity, edited by K.H. Petersen. Uppsala, Sweden: Scandinavian Institute of African Studies, 1987.

Sundkler, Bengt G.M. Bantu Prophets in South Africa. Second, expanded ed. London, Lutterworth Press, 1948.

Sundkler, Bengt G.M. Zulu Zion and Some Swazi Zionists. Oxford: Oxford University Press, 1976.

Sundkler, Bengt G.M., and Christopher Steed. A History of the Church in Africa. Edited by C. Steed. Cambridge: Cambridge University Press, 2000.

Taylor, Stephen. Shaka's Children: A History of the Zulu People. London: Harper Collins Publishers, 1994.

Turner, H.W. History of an African Independent Church: The Church of the Lord (Aladura). II vols. Vol. I. Oxford: Oxford University Press, 1967.

Turner, H.W. History of an African Independent Church: The Life and Faith of the Church of the Lord (Aladura). II vols. Vol. II. Oxford: Oxford University Press, 1967b.

Vilakazi, Absolom. Zulu Transformations: A study of the Dynamics of Social Change. Pietermaritzburg: University of Natal Press, 1965.

Wilson, Monica. Good Company: A Study of Nyakusa Age-Villages. Prospect Heights, Ill: Waveland Press, Inc, 1951. 